\title{
A Fibril Protein Antigen Specific to Spiroplasma
}

\author{
By R. TOWNSEND* AND D. B. ARCHER† \\ John Innes Institute, Colney Lane, Norwich NR4 7UH, U.K.
}

(Received 25 June 1982)

\begin{abstract}
An antiserum, raised in rabbits against honey-bee spiroplasma (BC3) fibril protein monomer, mol. wt 55000, excised from SDS-polyacrylamide gels, had precipitating activity against SDSdenatured fibril protein but not against the native protein. This antiserum was used to probe spiroplasma cell proteins separated by SDS-PAGE and blotted on to nitrocellulose filters. Antigens of mol. wt 55000 were identified in 13 different spiroplasmas, including a non-helical strain of Spiroplasma citri, representing five different sero-groups. The antiserum did not react with proteins in any of the Mycoplasma spp. or Acholeplasma spp. tested. Two-dimensional immunoelectrophoresis revealed variations in the amount of antigen in different isolates from the same sero-group. Peptide mapping by limited proteolysis showed that the fibril protein was highly conserved within a sero-group but that there was some heterogeneity between groups. All fibril proteins yielded common peptides recognised by the antiserum.
\end{abstract}

\section{INTRODUCTION}

Helical morphology and rotary motility are properties which distinguish members of the family Spiroplasmataceae (genus Spiroplasma) from other families of the Class Mollicutes. The reliability of morphology as a taxonomic criterion has been called into question by the isolation of non-helical and non-motile spiroplasma strains (Townsend et al., 1977). We have attempted to identify alternative properties characteristic of Spiroplasma.

Several different spiroplasmas release long flexuous fibrils 3-4 nm in diameter when cell lysis is induced by osmotic shock or non-ionic detergents (Stalheim et al., 1978; Williamson, 1974; Williamson \& Whitcomb, 1974). Fibrils purified from the honey-bee spiroplasma (BC3) are composed of a single protein of mol. wt 55000 unrelated to any bacterial proteins (Townsend $e t$ $a l ., 1980 a$ ). The function of these structures is unresolved but they may play a role in maintaining the helical morphology and rotary motility of these cell wall-less prokaryotes (Townsend et al., 1980a). Similar fibrils have been observed in a non-helical strain of Spiroplasma citri (Townsend et al., 1980 b). However, this organism lacks a single membraneassociated protein which may also be important in determining cell shape (Townsend et al., 1977).

We have examined the distribution of fibril protein among spiroplasmas from five different sero-groups (Junca et al., 1980) including a non-helical isolate of $S$. citri (Townsend et al., 1977). We have also looked for the presence of fibril protein in several Mycoplasma spp. and Acholeplasma spp. which have been reported to contain fibrillar structures (Göbel et al., 1981 ; Meng \& Pfister, 1980) or 'actin-like' proteins (Ghosh et al., 1978; Kahane \& Muhlrad, 1977; Neimark, 1977).

\section{METHODS}

Organisms. The following cloned cultures were used: sero-group I-1, S. citri SP-A (NCPPB 2565), R8A2 (ATCC 27556) and the non-helical isolate ASP-1 (NCPPB 3095); sero-group I-2, honey-bee spiroplasma BC3, obtained from T. B. Clark, Bioenvironmental Bee Laboratory, Plant Protection Institute, U.S. Department of

† Present address: ARC Food Research Institute, Colney Lane, Norwich, U.K. 
Agriculture, Beltsville, Maryland, U.S.A.; sero-group I-3, corn stunt spiroplasma E275 Rio Grande (ATCC 27954); sero-group I-4, tick spiroplasma 277F, obtained from R. F. Whitcomb, Insect Pathology Laboratory, Plant Protection Institute, U.S. Department of Agriculture, Beltsville, Maryland, U.S.A.; the other sero-group I spiroplasma, Cocos isolate (ATCC 33287); sero-group III, flower spiroplasma BNR1, obtained from R. F. Whitcomb, and Spiroplasma floricola 23-6A (ATCC 29989); sero-group IV, flower spiroplasma SR3 (ATCC 33095); sero-group V, tick spiroplasma SMCA (S221), obtained from R. F. Whitcomb; the unassigned spiroplasma, BREVI (ATCC 33474); Mycoplasma gallisepticum (NCTC 10115); Mycoplasma pneumoniae (NCTC 10119); Mycoplasma orale (NCTC 10112); Acholeplasma axanthum (NCTC 10138); Acholeplasma granularum (NCTC 10128); Acholeplasma laidlawii (NCTC 10116) and Acholeplasma oculi (NCTC 10150).

Culture. All spiroplasmas were grown in medium M1A (Jones et al., 1977) supplemented with 10\% (v/v) $10 \times$ CMRL tissue culture medium (GIBCO, Irvine, U.K.), instead of Schneider's Drosophila medium, and $10 \%$ (v/v) heat-inactivated foetal calf serum. Mycoplasmas and acholeplasmas were grown in a standard mycoplasma medium (Hayflick, 1965). Mycoplasma pneumoniae was provided as a washed cell suspension by $\mathbf{M}$. Sillis, Mycoplasma Reference Laboratory, Bowthorpe Road, Norwich, U.K.

Sample preparation. Cells were harvested from $100 \mathrm{ml}$ cultures by centrifugation $\left(20000 \mathrm{~g}\right.$ for $20 \mathrm{~min}$ at $\left.4{ }^{\circ} \mathrm{C}\right)$, washed in $10 \mathrm{mM}$-Tris [which was adjusted to $\mathrm{pH} 7.4$ with $\mathrm{HCl}$ and contained $7 \%(\mathrm{w} / \mathrm{v})$ sorbitol] and finally resuspended in $1 \mathrm{ml}$ water. The cells were disrupted with a sonic probe (Dawe type 7530A, London, U.K.) and stored at $-20^{\circ} \mathrm{C}$.

Triton X-100 extracts were made by adding $100 \mu \mathrm{g}$ total cell protein to $5 \mathrm{ml}$ detergent $(1 \%, \mathrm{w} / \mathrm{v})$ and centrifuging at $75000 \mathrm{~g}$ for $45 \mathrm{~min}$ at $4{ }^{\circ} \mathrm{C}$. The detergent-insoluble material was washed in $10 \mathrm{mM}$-Tris/HCl buffer and freezedried.

Protein assay. The protein content of cell suspensions and purified fibril preparations was determined by the Lowry method or, after solubilization in SDS, by Coomassie brilliant blue binding (Zaman \& Verwilghen, 1979).

$P A G E$. Samples of BC3 spiroplasma fibril protein, purified as described previously (Townsend et al., 1980a), or total cell proteins were freeze-dried and resuspended in SDS/2-mercaptoethanol sample buffer (Laemmli, 1970). Samples were electrophoresed in slabs of polyacrylamide $15 \times 12 \mathrm{~cm}$ in size and $0.15 \mathrm{~cm}$ thick, prepared according to Laemmli (1970) but containing either $15 \%(\mathrm{w} / \mathrm{v})$ acrylamide or $7 \cdot 5-25 \%$ linear gradients of acrylamide (Covey \& Hull, 1981). A potential difference of 100-150 V was applied until the bromophenol blue marker dye, incorporated into the sample, had reached the end of the gel. Gels were stained with Coomassie brilliant blue (Daniels \& Meddins, 1973).

Partial enzymic proteolysis. Proteins insoluble in Triton were separated on $15 \%$ polyacrylamide gels which were stained for $30 \mathrm{~min}$ in Coomassie brilliant blue and de-stained rapidly $(1 \mathrm{~h})$ in several changes of $15 \%(\mathrm{v} / \mathrm{v})$ methanol and 5\% (v/v) acetic acid. Bands corresponding to molecular weights of 55000 were excised and processed according to the method of Cleveland et al. (1977). Digestion with Staphylococcus aureus V8 protease $(0.25 \mu \mathrm{g}$ per gel slice) occurred in the stacking gel and the digestion products were separated by subsequent electrophoresis through a $15-30 \%$ linear gradient acrylamide gel. Gels were silver-stained using the method described by Oakley et al. (1980).

Preparation of antiserum. Fibrils were partially purified from $\mathrm{BC} 3$ cells harvested from 21 culture as previously described (Townsend et al., 1980a) but omitting the salt treatment before isopycnic centrifugation. Fibrils, equivalent to about $2 \mathrm{mg}$ protein, were solubilized in sample buffer and loaded across the entire width of two $15 \%$ acrylamide slab gels. After electrophoresis, slices of gel were stained to locate the $55000 \mathrm{~mol}$. wt polypeptide. The corresponding unstained strips of gel were excised, washed in $10 \mathrm{mM}$-Tris/ $\mathrm{HCl}$ buffer $\mathrm{pH} 7.0$ for $1 \mathrm{~h}$ and then homogenized in $3 \mathrm{ml}$ Freund's complete adjuvant and stored at $-20^{\circ} \mathrm{C}$. The total sample was divided into four $1.5 \mathrm{ml}$ samples which were injected subcutaneously into a New Zealand white rabbit at bi-weekly intervals. The animal was bled weekly after the last injection. The activity of the antiserum was monitored by double immunodiffusion (Crowle, 1961) against purified fibril protein or BC3 cells solubilized in SDS ( $1 \%$, w/v). Samples showing precipitating activity were pooled for use in these experiments.

Protein blotting and immunodetection of antigens. Proteins solubilized in SDS sample buffer and separated by PAGE were blotted on to $S \& S$ nitrocellulose membrane filters $(0.45 \mu \mathrm{m}$ pore diameter; Anderman \& Co., East Molesey, U.K.) by diffusion in the presence of $4 \mathrm{M}$-urea (Bowen et al., 1980). The pattern of transferred proteins was revealed using Coomassie brilliant blue stain followed by rapid de-staining in $50 \%$ methanol and $5 \%$ acetic acid to avoid damaging the nitrocellulose filters. The double antibody technique used to detect bound antigens was based on that of Towbin et al. (1979). Dried blots were incubated for $2 \mathrm{~h}$ in $20 \mathrm{mM}$-Tris/HCl buffer $\mathrm{pH} \mathrm{7.4}$ containing $0.9 \%(\mathrm{w} / \mathrm{v})$ sodium chloride and $1 \%(\mathrm{w} / \mathrm{v})$ bovine serum albumin (BSA; fraction $\mathrm{V})$ to block nonspecific binding sites. The primary antiserum or pre-immune serum was then added at a concentration of $1: 1000$ and the blots were incubated overnight. After washing five times with $200 \mathrm{ml}$ Tris-buffered saline without BSA the blots were incubated for $2 \mathrm{~h}$ in Tris-buffered saline with BSA containing a $1: 2000$ concentration of goat antiserum raised against rabbit $\mathrm{IgG}$ and conjugated to horse-radish peroxidase (Miles, Slough, U.K.). After further washing, the bound conjugate was developed by incubating in $10 \mathrm{mM}$-Tris/ $\mathrm{HCl} \mathrm{pH} 7 \cdot 2$ containing $0.01 \%$ 
(v/v) hydrogen peroxide and $0.05 \%(w / v)$ 4-chloro-1-naphthol (Hawkes et al., 1982). Areas to which antibodies had bound were identified by development of a blue coloured product which was insoluble in aqueous solutions and light-stable. All incubations were performed at room temperature.

Immunoelectrophoresis. Two-dimensional immunoelectrophoresis using proteins separated by SDS-PAGE was performed as described previously (Archer \&Townsend, 1981). Comparisons were made using stained first dimension gels which had not been electrophoresed in the second dimension.

\section{RESULTS}

\section{Double diffusion tests}

Serum from rabbits immunized with SDS-denatured fibril protein formed strong precipitin lines against antigen or BC3 cells solubilized in SDS but failed to react with sonicated preparations of purified fibrils, BC 3 cells or $0.1 \%$ SDS.

\section{Immunodetection of antigens on protein blots}

A comparison of stained blots of $\mathrm{BC} 3$ proteins and corresponding gels stained before and after blotting showed that most of the detectable material had been transferred to the nitrocellulose filters. All the major proteins appeared to transfer quantitatively irrespective of molecular weight except one of 25000 which was selectively retained within the gel (Fig. 1a).

Blots of total BC3 proteins probed with antiserum raised against BC3 fibril protein showed large quantities of antigen located at a position equivalent to a molecular weight of 55000 (Fig. $1 b$, track 3). Two or three minor antigens of lower molecular weight were also detected, in particular one of mol. wt 25000 . Similarly, probed blots of all the spiroplasmas detailed in Methods, including the non-helical isolate, ASP-1, also revealed a major antigen of mol. wt 55000 (Fig. 1 b). The amount of antigen detected varied between spiroplasmas. The SR-3 spiroplasma (Fig. 1b, track 8) and the BREVI (Fig. 1b, track 10) isolates, loaded at a concentration of $5 \mu \mathrm{g}$ total cell protein, produced relatively faint bands which became quite clear if the loading was increased fivefold (Fig. $1 c$ ). Some spiroplasmas contained small amounts of antigenic material of mol. wt $30000-40000$ but nearly all bound antibodies to a protein, in the range 23000-25000, which was present in particularly large amounts in the corn stunt spiroplasma. Some smearing of antigenic material was associated with those strains which normally produce low cell yields in culture and was attributed to interference with solubilization of cellular proteins by the higher proportion of precipitated medium components (Townsend \& Daniels, 1981). Non-specific binding of globulins or spiroplasma peroxidase activity was not observed when duplicate blots were probed with pre-immune serum.

The antiserum did not recognize any antigens in any of the Mycoplasma spp. or Acholeplasma spp. examined, even when the loading was increased to $50 \mu \mathrm{g}$ of total cell protein (Fig. $1 b$, tracks 11-16).

\section{Immunoelectrophoresis}

A single rocket was formed in the antiserum-containing slab, located directly over the fibril protein band in the first-dimension gel at a position equivalent to a molecular weight of 55000 (Fig. 2a). Rockets of similar shape were produced in the same position relative to gels of BC3 whole cell proteins (Fig. $2 b$ ). No other rockets were visible and no stainable material remained in the first-dimension gel. The absence of precipitated 25000 mol. wt material almost certainly reflects the reduced sensitivity of this technique compared to the immunodetection of antigens on protein blots. Spiroplasmas from sero-groups I and V produced sharp rockets of varying dimensions at the $55000 \mathrm{~mol}$. wt position (Fig. 2c). After corrections for differences in protein loading, the quantities of precipitated antigen were determined on the basis of the area below each rocket relative to those produced by known concentrations of purified fibril protein (Table 1). Only the corn stunt spiroplasma gave rise to an additional rocket at the $25000 \mathrm{~mol}$. wt position. Group III and group IV spiroplasmas only produced rockets when a total of $200 \mu \mathrm{g}$ cell protein was loaded and the concentration of antiserum doubled. Even then the rockets stained too diffusely to be measured accurately (Fig. $2 d$ ). 


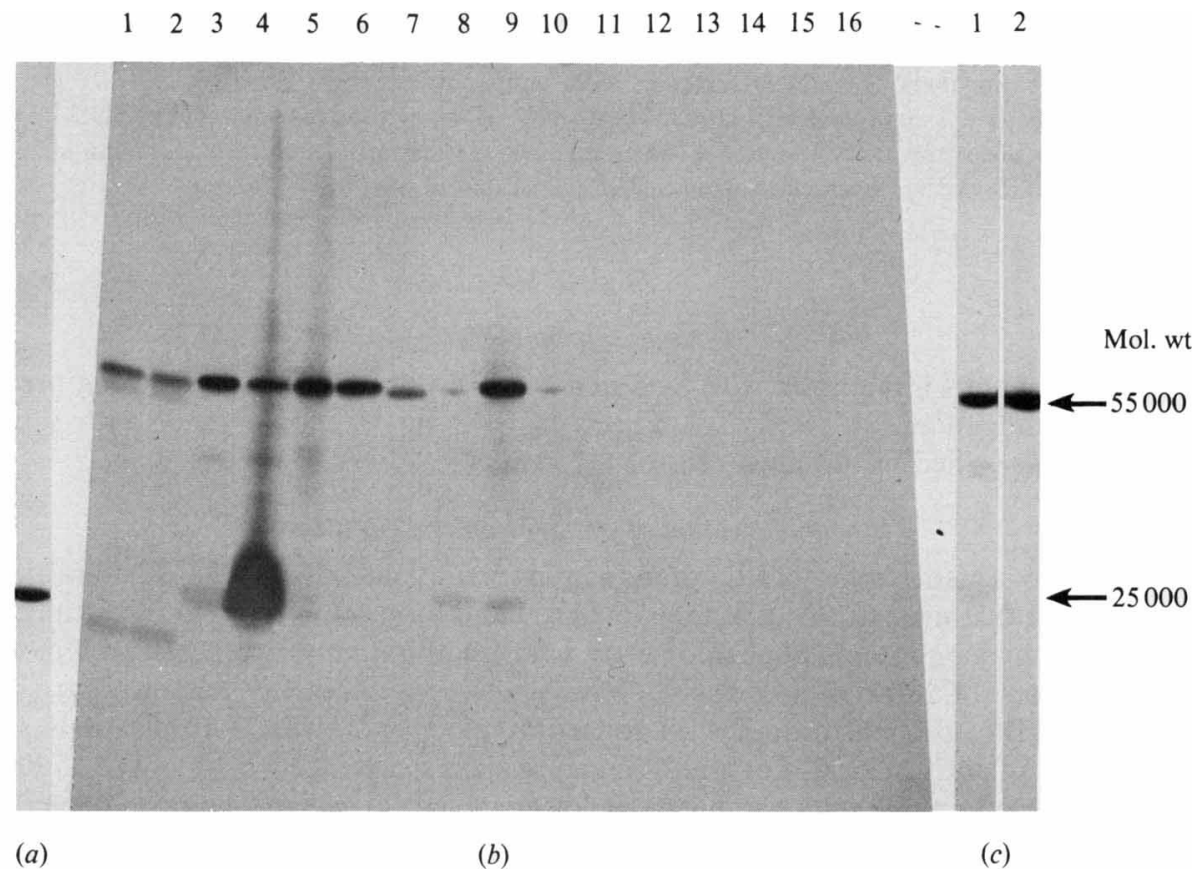

Fig. 1. (a) Polyacrylamide gel, stained after blotting of SDS soluble BC3 whole cell proteins to nitrocellulose filters (cf. Fig. $1 b$, track 3). (b) Immunodetection of antigens bound to filters. Samples $(5 \mu \mathrm{g})$ of SDS-solubilized total cell protein were separated by electrophoresis in a linear gradient polyacrylamide gel and blotted on to a nitrocellulose filter which was then probed with antiserum raised against SDS-denatured BC3 fibril monomer, mol. wt 55000, and developed as described. The tracks were loaded as follows: track 1, SP-A ; track 2, ASP-1 ; track 3, BC3; track 4, E275; track 5, 277F ; track 6, Cocos isolate; track 7, BNR1; track 8, SR-3; track 9, SMCA; track 10, BREVI; track 11, $M$. gallisepticum; track $12, M$. homonis; track $13, M$. pneumoniae; track 14, A. axanthum; track 15, A. oculi; and track 16, A. laidlawii. (c) As Fig. $1 b$ but loaded with $25 \mu \mathrm{g}$ SDS-solubilized total cell protein from: track 1, SR-3; track 2, BREVI.
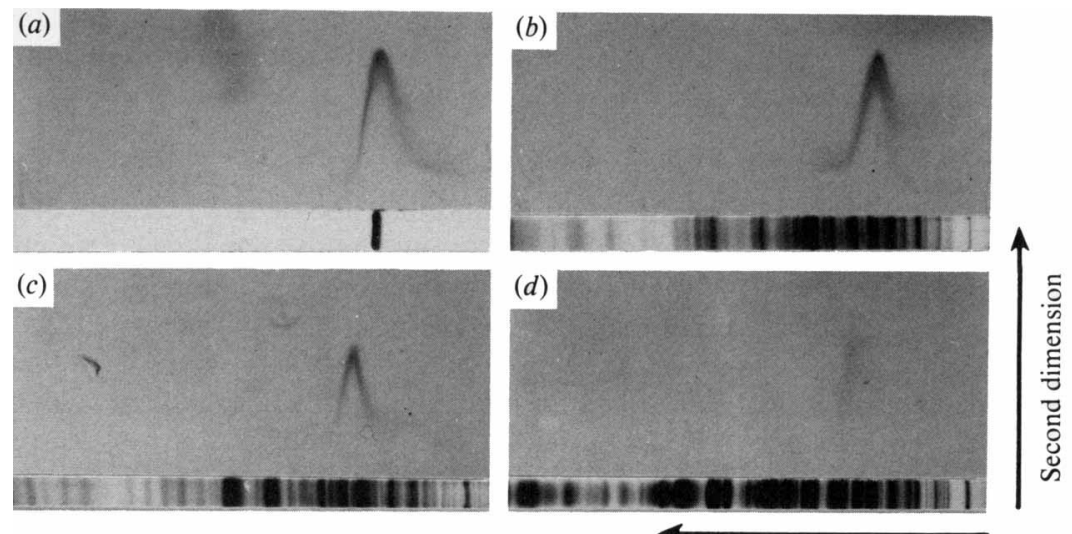

First dimension

Fig. 2. Immunoelectrophoresis of SDS-solubilized antigens. The lower gels were polyacrylamide gels loaded at the right-hand side as viewed. (a) Purified BC3 fibril protein, mol. wt 55000. (b-d) SDSsolubilized whole cell proteins from: (b) BC3 $(50 \mu \mathrm{g}),(c)$ SMCA $(100 \mu \mathrm{g})$, and $(d)$ SR-3 $(200 \mu \mathrm{g})$. Agarose second-dimension gels in deoxycholate contained antiserum against SDS-denatured BC3 fibril monomer. 


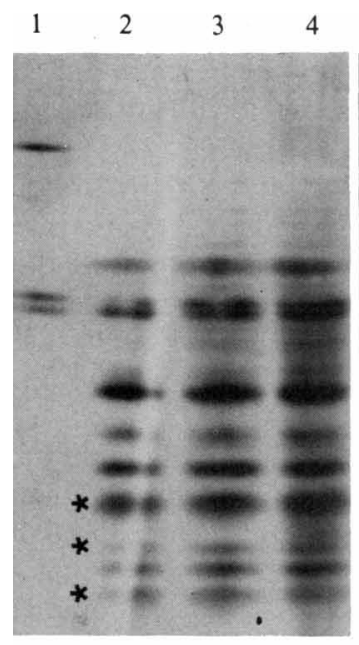

(a)

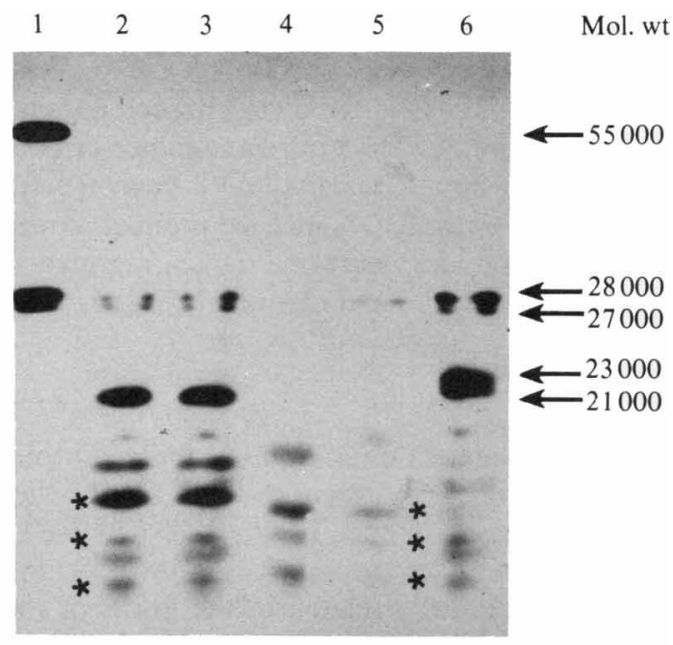

(b)

Fig. 3. (a) Electrophoretic separation of peptides generated by limited proteolysis with $S$. aureus V8 protease of gel slices containing 55000 mol. wt material from: track 1, purified BC3 fibrils (without enzyme); track 2, purified BC3 fibrils. Tracks 3-6, Triton-insoluble proteins from: track 3, BC3; track 4, SP-A; track 5, BNR1; and track 6, SR-3. Track 7 contained enzyme only. Asterisks indicate the three peptides in each digest with similar staining properties. (b) Peptides from V8 digests were blotted on to a nitrocellulose filter which was then probed with antiserum against SDS-denatured BC3 fibril protein monomer to detect peptides binding antibodies. Digests were as follows: track 1, purified BC3 fibril protein (no enzyme); track 2, purified BC3 fibril protein; track 3, BC3; track 4, BNR1; track 5, SR-3 and track 6, SMCA.

Table 1. Concentration of fibril antigen in different spiroplasmas as determined by immunoelectrophoresis

$\begin{array}{ccc}\text { Sero-group } & \text { Strain } & \begin{array}{c}\text { Fibril antigen } \\ \text { concentration [mg } \\ (100 \mathrm{mg} \text { total cell } \\ \text { protein })^{-1} \text { ] }\end{array} \\ \text { I-1 } & \left\{\begin{array}{l}\text { S. } \text { citri } \text { R8A2 } \\ \text { S. } \text { citri } \text { SP-A }\end{array}\right. \\ \text { I-2 } & \text { BC3 } & 0 \cdot 8 \\ \text { I-3 } & \text { E275 } & 0 \cdot 5 \\ \text { I-4 } & \text { 277F } & 3 \cdot 1 \\ \text { III } & \text { SMCA } & 1 \cdot 3 \\ & & 0.9\end{array}$

\section{Analysis of proteolysis products}

Upon re-electrophoresis of gel slices containing undigested fibril protein, two additional peptides of mol. wt 28000 and 27000 appeared. It was assumed that these arose as a consequence of the acid hydrolysis of the monomer during primary staining. They proved partially resistant to digestion with V8 protease but all the remaining $55000 \mathrm{~mol}$. wt material was digested and reproducibly yielded seven major peptides with molecular weights below 21000 . We observed that each peptide stained with a different shade of colour. Digestion of the equivalent polypeptide excised from the separation of total $\mathrm{BC} 3$ Triton-insoluble proteins generated an identical set of fragments as did the digests of fibril protein from other group I spiroplasmas (Fig. 3a). Protein from the SMCA spiroplasma was cleaved to give reduced quantities of the same fragments and an additional product of mol. wt 23000. The peptide patterns generated by digestion of $55000 \mathrm{~mol}$. wt protein from BNRl and SR-3 were similar but were significantly different to that derived from the BC3 protein (Fig. $3 a$ ). However, all the digests contained at least three peptides which varied slightly in molecular weight but which stained the same colour 
(Fig. $3 a$ ). In order to investigate the possibility that these peptides were derived from an antigenically conserved portion of the protein, duplicate digests were performed and the cleavage fragments blotted on to nitrocellulose filters which were then probed with antiserum to the SDS-solubilized BC3 fibril monomer or pre-immune serum.

Antibodies bound to all the V8 cleavage fragments from the BC3 and SMCA proteins including the extra 23000 mol. wt product. Antibody binding to BNR1 and SR-3 peptides was much weaker and at least one major fragment in each digest was unrecognized, but the three conserved peptides were identified (Fig. $3 b$ ). No peptides reacted with pre-immune serum.

\section{DISCUSSION}

By immunodetection of SDS-solubilized proteins blotted on to nitrocellulose filters we have demonstrated that representatives of four of the five recognized sero-groups within the family Spiroplasmataceae (Junca et al., 1980), as well as the BREVI spiroplasma [which probably represents a new sero-group (R. E. Davis, personal communication )], contain a $55000 \mathrm{~mol}$. wt protein antigenically related to the fibrils of the $\mathrm{BC} 3$ spiroplasma. We did not examine any representatives of sero-group II which comprises the non-cultivable Drosophila sex-ratio spiroplasmas. At least one member of this group has been shown to contain fibrils indistinguishable by electron microscopy from those observed in $S$. citri (Williamson, 1974). Since the non-helical isolate of $S$. citri contains fibril antigen, this protein can be used as a marker by which spiroplasmas exhibiting aberrant morphologies in culture may be correctly identified. The failure of the antiserum to react with any proteins in the Mycoplasma spp. or Acholeplasma spp. examined supports our previous assertion (Townsend et al., 1980a) that spiroplasma fibrils are unrelated to 'actin-like' proteins isolated from mycoplasmas or to the fibrillar elements which occur in $M$. pneumoniae. These structures are almost certainly unique to Spiroplasma.

The antiserum also contained antibodies which recognized a 25000 mol. wt protein in BC3 which transferred with low efficiency to nitrocellulose. This protein is probably related to spiralin (Wróblewski et al., 1977), the major membrane antigen in S. citri (Archer \& Townsend, 1981). We have previously reported that large quantities of this protein co-purify with fibrils (Townsend et al., 1980a). Purified spiralin can form dimers, even in SDS gels, which give rise to a second minor rocket in two-dimensional immunoelectrophoretic separations (Archer \& Townsend, 1981). The dimer ran only slightly faster than fibril protein on SDS gels and may have been excised with the fibril protein. The $\mathrm{BC} 3$ spiralin is highly antigenic and only small quantities are required to elicit specific antibodies. Similar low molecular weight proteins were detected in all group I spiroplasmas except the Cocos isolate, as well as the BNR1 and SR3 spiroplasmas. This wide distribution of antigenically related proteins suggests they may have functional similarity. It has been proposed (Townsend et al., 1980 a) that spiralin may play a role in determining the cell shape of $S$. citri, possibly in association with fibrils and a $39000 \mathrm{~mol}$. wt protein absent from the non-helical isolate ASP-1 (Townsend et al., 1977).

The quantity of fibril protein in BC3 cells, determined by two-dimensional immunoelectrophoresis, is in fairly close agreement with the estimate of $2 \%$ of total cell protein based on the yield of purified material (Townsend et al., 1980a). The variations in antigen concentration between different group I spiroplasmas could be correlated with the amount of stainable 55000 mol. wt material resolved by SDS-PAGE (Daniels et al., 1980). These findings are supported by direct electron microscopic observations which show that cells of the $\mathrm{BC} 3$ spiroplasma release about five times as many intact fibrils as cells of $S$. citri (SP-A) when lysed in situ (R. Townsend, unpublished observation). The variations in fibril protein concentration between different serogroup I organisms, and in particular the closely related BC3 and SP-A spiroplasmas, should provide a starting point for comparative studies to investigate the function of spiroplasma fibrils.

Both the BNR1 and SR-3 spiroplasmas contained much more 55000 mol. wt material than was indicated by the size of the rockets generated during immunoelectrophoresis. The unusual appearance of these rockets also indicated that there was antigenic heterogeneity between fibril 
proteins from different sero-groups. Peptide mapping of V8 protease products, in conjunction with blotting and antibody probing, confirmed that the fibril protein is highly conserved amongst group I spiroplasmas and is closely related to the $55000 \mathrm{~mol}$. wt protein in the group V spiroplasma, SMCA. Although corresponding proteins in spiroplasmas from other sero-groups exhibit variations in primary structure, the monomer molecular weight is not significantly altered. Furthermore, there is sufficient conservation of structure to maintain at least one recognition site for antibodies directed against BC3 fibril protein. The wide specificity of the antiserum was reflected in its capacity to react with all the peptides generated by proteolysis of the homologous BC3 antigen. This may be a general feature of antiserum prepared against SDSdenatured proteins and leads us to speculate that a similar antiserum raised against the native protein subunit might be more specific.

Silver staining proved to be a simple and relatively inexpensive alternative to the production of radioactively labelled substrates and the detection of peptide fragments by autoradiography as described by Cleveland et al. (1977). We found it to be about 50 times more sensitive than Coomassie brilliant blue staining. It also introduces an extra dimension of colour into the analysis of products which could probably be enhanced still further by using a recently described technique (Sammons et al., 1981). The relationship between colour of staining and primary structure (Sammons et al., 1981) enabled us to predict relationships between different peptides which were subsequently confirmed by antibody binding.

The characteristic helical morphology of cultured spiroplasmas is frequently lost in the tissues of insect and plant hosts (for review, see, Markham \& Townsend, 1979) where they become indistinguishable from the non-cultivable mycoplasma-like organisms associated with 'yellows' diseases of plants. The presence of fibril protein is diagnostic for spiroplasmas and it can be detected at very low levels by the techniques described in this paper. In this way, the notion that other plant mycoplasma-like organisms are in fact non-cultivable spiroplasmas (Davis, 1974) can be tested directly. Also, unusual fibril structures composed of thin filaments 4-6 nm in diameter have been observed in the brains of animals infected with scrapie (Merz et al., 1981) and electron microscopic evidence has been interpreted to indicate the presence of a spiroplasma in post-mortem tissue from a patient with Creutzfeld-Jakob disease (Bastian 1979; Bastian et al., 1981). It should now be possible to investigate the implication of spiroplasma involvement in any clinical situation or pathogenesis in plants without culture of the agent.

We thank all those who have supplied us with cultures and cell preparations and express our gratitude to Sally J. Curson for technical assistance. This work was carried out under MAFF licence number PHF49/41 issued under the Destructive Pests and Diseases of Plants Order 1965.

\section{REFERENCES}

ARCHER, D. B. \& TownSEND, R. (1981). Immunoelectrophoretic separation of spiroplasma antigens. Journal of General Microbiology 123, 61-68.

Bastian, F. O. (1979). Spiroplasma-like inclusions in Creutzfeld-Jakob disease. Archives of Pathology and Laboratory Medicine 103, 65.

Bastian, F. O., Hart, M. N. \& Cancilla, P. A. (1981). Additional evidence of spiroplasma in CreutzfeldJakob disease. Lancet 1, 660 .

Bowen, B., Steinberg, J., Laemmli, U. K. \& Weintraub, H. (1980). The detection of DNAbinding proteins by protein blotting. Nucleic Acids Research 8, 1-20.

Cleveland, D. W., Fischer, S. G., Kirschner, M. W. \& LaEmmLI, U. K. (1977). Peptide mapping of limited proteolysis in sodium dodecyl sulphate and analysis by gel electrophoresis. Journal of Biological Chemistry 252, 1102-1106.

CoveY, S. N. \& Hull, R. (1981). Transcription of cauliflower mosaic virus DNA. Detection of tran- scripts, properties and location of the gene encoding the virus inclusion body protein. Virology 111, 463474.

Crowle, A. J. (1961). Immunodiffusion. New York: Academic Press.

Daniels, M. J. \& Meddins, B. M. (1973). Polyacrylamide gel electrophoresis of mycoplasma proteins in sodium dodecyl sulphate. Journal of General Microbiology 76, 239-242.

Daniels, M. J., Archer, D. B., Stephens, M. A., Townsend, R., Longland, J. M. \& Best, J. (1980). Comparison of spiroplasmas by polyacrylamide gel electrophoresis of cell proteins. Current Microbiology 4, 377-380.

DAvis, R. E. (1974). New approaches to the diagnosis and control of plant yellows diseases. In Proceedings: Third International Symposium on Virus Diseases of Ornamental Plants, 11-15 September 1972, no. 36, 289-302C. Edited by R. H. Lawson \& M. K. Corbett. 
Ghosh, A., Maniloff, J. \& Gerling, D. A. (1978). Inhibition of mycoplasma cell division by cytochalasin B. Cell 13, 57-64.

GÖBEL, U., SPETH, V. \& BREDT, W. (1981). Filamentous structures in adherent Mycoplasma pneumoniae cells treated with non-ionic detergents. Journal of Cell Biology 91, 537-543.

Hawkes, R., Niday, E. \& Gordon, J. (1982). A dotimmunobinding assay for monoclonal and other antibodies. Analytical Biochemistry 119, 142-147.

HAYFLICK, L. (1965). Tissue cultures and mycoplasmas. Texas Reports on Biology and Medicine 23, 285303.

Jones, A. L., Whitcomb, R. F., Williamson, D. L. \& COAN, M. E. (1977). Comparative growth and primary isolation of spiroplasmas in media based on insect tissue culture formulations. Phytopathology 67 , 738-746.

Junca, P., Saillard, C., Tully, J., Garcia-Jurado, O., Degorce-Dumas, J. R., Mouches, C., VigNAUlT, J. C., Vogel, R., MCCOY, R., WhitCOMB, R., Williamson, D., Latrille, J. \& Bové, J. M. (1980). Caracterisation de spiroplasmes isolés d'insects et de fleurs de France continentale, de Corse et du Maroc; proposition pour une classification de spiroplasmes. Comptes rendus hebdomadaires des séances de l'Académie des sciences D290, 1209-1212.

Kahane, I. \& MuHLRad, A. (1977). Actin-like proteins from mycoplasmas. Proceedings of the Annual Meeting of the Israel Society for Biochemistry. Israel Journal of Medical Sciences 13, 956.

LAEMMLI, U. K. (1970). Cleavage of structural proteins during the assembly of the head of bacteriophage T4. Nature, London 227, 680-685.

MARKhaM, P. G. \& TownSEND, R. (1979). Experimental vectors of spiroplasmas. In Leafhopper Vectors and Plant Disease Agents, pp. 415-443. Edited by K. Maramorosch \& K. F. Harris. New York: Academic Press.

Meng, K. E. \& Pfister, R. M. (1980). Intracellular structures of Mycoplasma pneumoniae revealed after membrane removal. Journal of Bacteriology 144, 390-399.

MERZ, P. A., SOMER VILle, R. A., WisNIEWSKI, H. M. \& IQBAL, K. (1981). Abnormal fibrils from scrapie infected brain. Acta neuropathologica 54, 63-74.

NeIMARK, H. C. (1977). Extraction of an actin-like protein from the prokaryote Mycoplasma pneumoniae. Proceedings of the National Academy of Sciences of the United States of America 74, 4041-4045.
OAKLEY, B. R., KIRSCH, D. R. \& MORRIS, R. N. (1980). A simplified ultrasensitive silver stain for detecting proteins in polyacrylamide gels. Analytical Biochemistry 105, 361-363.

Sammons, P. W., Adams, L. D. \& Nishizawa, E. E. (1981). Ultrasensitive silver-based color staining of polypeptides in polyacrylamide gels. Electrophoresis 2, 141-147.

Stalheim, H. V., Ritchie, A. E. \& Whitcomb, R. F. (1978). Cultivation, serology, ultrastructure and virus-like particles of spiroplasma 277F. Current Microbiology 1, 365-370.

Towbin, H., Staehelin, T. \& GoRdon, J. (1979). Electrophoretic transfer of proteins from polyacrylamide gels to nitrocellulose sheets: procedure and some applications. Proceedings of the National Academy of Sciences of the United States of America 76, $4350-4354$.

Townsend, R. \& Daniels, M. J. (1981). Physicochemical characterisation of plant and insect mycoplasma. In Plant and Insect Mycoplasma Techniques, pp. 268-306: Edited by M. J. Daniels \& P. G. Markham. London: Croom Helm.

Townsend, R., Markham, P. G., Plaskitt, K. A. \& DANIELS, M. J. (1977). Isolation and characterization of a non-helical strain of Spiroplasma citri. Journal of General Microbiology 100, 15-21.

Townsend, R., Archer, D. B. \& Plaskitt, K. A. $(1980 a)$. Purification and preliminary characterisation of spiroplasma fibrils. Journal of Bacteriology 142, 694-700.

Townsend, R., Burgess, J. \& Plaskitt, K. A. $(1980 \mathrm{~b})$. Morphology and ultrastructure of helical and non helical strains of Spiroplasma citri. Journal of Bacteriology 142, 973-981.

Williamson, D. L. (1974). Unusual fibrils from the spirochete-like sex ratio organism. Journal of Bacteriology 117, 904-906.

Williamson, D. L. \& Whitcomb, R. F. (1974). Helical, wall-free prokaryotes in Drosophila, leafhoppers and plants. Colloques de l'Institut National de la Santé et de la Recherche Médical 33, 283-290.

Wróblewski, H., Johansson, K.-E. \& HJérten, S. (1977). Purification and characterisation of spiralin, the main protein of the Spiroplasma citri membrane. Biochimica et biophysica acta 465, 275-289.

ZAMAN, Z. \& VERWILGHEN, R. L. (1979). Quantitation of proteins solubilized in sodium dodecyl sulphatemercaptoethanol-Tris electrophoresis buffer. Analytical Biochemistry 100, 64-69. 